\title{
The Importance of Knowledge Management in World of Information
}

\author{
Prof. Dr. Sanie Doda \\ Lecturer, Aleksander Moisiu University \\ Durres, Albania \\ E- mail: sanijedoda@yahoo.com
}

Received: January 01, 2017 Accepted: January 28, 2017 Published: February 18, 2017

doi:10.5296/ijhrs.v7i1.10764 URL: http://dx.doi.org/10.5296/ijhrs.v7i1.10764

\begin{abstract}
Globalization and innovation depends on the knowledge of individuals. Coordination of knowledge and talent of the people is important component of performances and development of the organization. Knowledge is world power. Knowledge, if managed properly, turns into value and adds higher yields in life and work. It comes as a result of time to certain degrees and starts with general empirical data, where facts and observations are "raw material". Content of such data comprise what we call information. Knowledge is next to the last of "Information pyramid" at the top of which is wisdom.

Albania's integration process is accompanied with a "boom" of information flowing. Such information is a great endowment in acquisition of knowledge, experiences and best practices. We think that is required maximum exploitation of existing structures.

Knowledge is acquired in allocated conditions and for this its treatment is a job for appropriate structures of human resources management.
\end{abstract}

Keywords: Knowledge, Manage, Human resource management (HRM), Codification, Knowledge dissemination. 


\section{Macrothink}

\section{Introduction}

\subsection{Definition of $K M$}

Different authors have defined KM in different prospective. This perhaps as a consequence of perceptions, understandings and experiences they have. Harrison ${ }^{\mathrm{i}}$ argues that, $\mathrm{KM}$ is a complex concept paper that has been defined as any process or practice of creating, acquiring, capturing, sharing and using knowledge, wherever it resides, to enhance learning and performance in organization. Goal: augmentation of learning and organizational performance. Willard $^{\mathrm{ii}}$ on the other hand argues that $\mathrm{KM}$ as the development and facilitation of collaborative working, recognizing the interconnected nature of people, processes and information, in organizations that have become regional or global. In support of this definition, $\mathrm{KM}$ is a solicitation and is used in and outside the organization. This means the simple and meaningful fact that KM is an inexhaustible resource that influences in the rise of organizational performance. Davenport and Prusak ${ }^{\text {iii }}$ argue that in organization, knowledge is not embedded only in documents or repositories but also in organizational routines, processes, practice and norms implemented day by day.

\subsection{Explicit and Tacit Knowledge}

Knowledge is divided into two approaches, explicit and tacit ${ }^{\mathrm{iv}}$. Explicit knowledge is that aspect of knowledge that can be easily expressed or articulated in language. For instance, manuals, project reports, a map of a city center, etc. on the other hand, tacit knowledge is that part of a knowledge that is embedded in people's experience through human experience. And it cannot be articulated and is live knowledge that would not survive outside the human system through which its dynamics is sustained. For instance, an older and experienced manager is able to immediately understand employees condition or an experienced doctor intuitively understands the patient's condition whether it can be recovered or not.

\subsection{Dimensions of $K M$}

KM covers four main dimensions. These are knowledge creation, knowledge embodiment, knowledge dissemination and knowledge use $\mathrm{v}^{\mathrm{v}}$. Knowledge creation falls under two areas; social and scientific construction.

Scientific knowledge construction is whereby knowledge is a justified true belief or law. We can mention here the law of gravity.

Social construction of knowledge is that knowledge which is constructed by a community of practice like scientists, engineers, consultants and scholars ${ }^{\mathrm{vi}}$. For instance, management knowledge constructivists like Taylor's Scientific Management, Elton Mayo of Human Relation Theory etc.

Knowledge embodiment is the social interchange of knowledge within an organization ${ }^{\text {vii }}()$. This is exercised through KM activities like sharing, informal meetings, dialogues, discussions, exchange of views, observations, brainstorming, conferences and the use of information technology like e-mail and intranet. For instance, academics and students at universities may now exchange ideas for different issues aiming mainly at their performance. 


\section{$\Lambda$ Macrothink}

Their goal is to pass their exams achieving higher results.

Knowledge dissemination is the transfer of knowledge from one person to another, depending on the nature and purpose of an organization. For instance, organization issues rules and manuals and organizes workshops for the students to be known with the latest experiences. Among the experiences we can mention "Lessons Learned", where employees who have a better experience transmit the gained experience to newcomers in different forms and methods, like formal and informal meetings. Baumard ${ }^{\text {viii }}$ argues that education faculties are themselves knowledge organizations.

The use of knowledge is meant for economic benefits. However, this varies depending on the purpose and mission of an organization. Knowledge can be used for product development, service delivery, improving organization's efficiency, cost and time saving and community development.

\subsection{Goal of KM}

The goal of KM is to identify and capture the knowledge of the organizations so that they can be exploited as a resource, knowledge as assets, knowledge as something to be leveraged and the value of intellectual capital ${ }^{\mathrm{ix}}$. Walton ${ }^{\mathrm{x}}$ argues that $\mathrm{KM}$ is the argument that much of learning about key activities is held in the experience of individuals and that this is lost when too many key leave.

\subsection{Focus of KM}

KM focuses on knowledge sharing in a team to ensure that knowledge is transferred from individuals to collective or social knowledge in order to secure continuous innovation and problem solving and in organization. For instance, launch of a new product in market as a way to show constant success.

\section{Practice of KM}

There are two aspects of KM, personalization and codification ${ }^{\mathrm{xi}}$. Personalization rests on person-to-person contacts of sharing knowledge through dialogue and brainstorming. And information technology (email and intranet) and telephone is used for networking among community of practice. This strategy is widely used among scientists at different research they conduct.

Meanwhile, codification is the process of KM that relies on a people-to-document. That is, vital knowledge from knowledge workers is removed and kept in a computer or electronic repository. For instance, CD-ROM and Internet have a lot of knowledge on various subjects for people's consumption.

Finally, according to McShane and Von Glinow ${ }^{\text {xii }}$, some codified explicit knowledge is of such value that organization has to manage it as a legal entity with property rights, like the right of producing weapons. Such conclusion is reached having seen that KM focuses on knowledge sharing in a team for organizational development and sustainability. 


\subsection{KM as a Managerial Fad}

The advent of KM has encountered mixed reactions. According to Scarborough and Swan ${ }^{\text {xiii. }}$ "There is little doubt that we have entered the knowledge economy where what organizations know is becoming more important than the traditional sources of economic power-capital, land, plant and labor". However, Ruggles ${ }^{\text {xiv }}$ argues that to a growing number of companies, $\mathrm{KM}$ is more than just a buzzword or a sales pitch, which adds values through active leverage like: know-how, experience and judgment resident outside and inside organization. Davenport and Prusak ${ }^{\mathrm{xv}}$ argued that the creation of the position of Chief Knowledge Officer as a response to KM was felt as a passing fad.

McAdam and Reid ${ }^{\mathrm{xvi}}$ carried out a comparative research on the perception of the public and private sector on KM comprising of ninety-seven informants and eight workshops. The findings show that, KM has been recognized in the public sector as opposed to the private sector. However, KM is an emergent rather than an established system in most organizations. Their findings confirmed that $\mathrm{KM}$ is an emergency for organizations. Team leaders and employees are seen as having a much lesser role. The appropriate state offices also confirm McAdam and Reid findings. This shows that $\mathrm{KM}$ is a new and necessary concept in managerial aspect.

Strategic level manager create the vision of knowledge necessary to organization and this helps including middle and lower level managers up to the last employee. In these companies, $\mathrm{KM}$ is understood as a managerial fad fully integrated.

\subsection{Managerial Predications}

Rise and fall of managerial fad-Organizational learning, scientific management and human relation management show that fads often change and their value is determined by time.

Scarborough and Swan argue that popularity of such a "style" in managerial literature is almost the same in many countries. Meanwhile, the interest in KM is actually on higher rates. Buchanan and Huczynski ${ }^{x v i i}$ argue that $\mathrm{KM}$ is a manifesto of organizational fad, which goes along from old fashions to new ones with particular interest on humans, as a potential force of economic productivity or service. This implies that changes in socio-economic environment makes the scientists to continue cultivate new fads as a necessary mechanism.

\subsection{KM as a Point of Reference for Effective Operations inside Organization}

$\mathrm{KM}$ and its dissemination are evident. It assures strong points by helping people to operate effectively inside the organization. A labor force includes people with different views and experiences. This produces the possibility for ideas to be discussed and easily shared. In this way it facilitates problem solving. This can be related to the proverb "One mind is nothing, two are one".

Referring to education theory there are two lines: formal and non-formal education. Formal education is taught at schools, colleges and universities and different training institutions. Main method of education is teaching and lecturing. On the other hand, non-formal education is possible through the establishment of a social climate within the group. 
HRD is divided in two: individual and group. For the individual is seen as development of abilities, a step forward in career, while for the group as a good opportunity to improve capacity and assert the necessary leadership and improve efficiency for decision-making process.

This means helping the group to accomplish plans, programs and amount number of activities with the goal to develop people.

The success of organizing teaching in-group depends planning the right strategy, creating harmony and reciprocal relations inside the group, improving knowledge, ability and experience of group members. KM requires a clear vision for organizational leadership.

Web ${ }^{\text {xiii }}$ argues that $\mathrm{KM}$ practice in organization requires clear statement from higher instances to the lowest one, the necessary communication mechanisms for information distribution, understanding and including the appointed goal, necessary planning and training program, adaptable systems and procedures as well constant monitoring to make sure that everything is in the right place. This means that in case of lacking a clear organizational vision KM will be impossible. For instance, Lester ${ }^{\text {xix }}$ argues that lacking a clear policy, individual knowledge and evaluation system negatively influence in its distribution inside the organization.

\section{Implication of KM on Respective Structures for HRD.}

The emergence of KM in organization has set forth the role of responsible structures starting from the main problem that HRD will depend from learning process and necessary abilities. Some of the main duties are:

\subsection{Protagonist of $K M$}

KM has placed these structures as key ones in this process. Walton ${ }^{\mathrm{xx}}(1999, \mathrm{p} .76-84)$ argues that it is a duty and responsibility of appropriate structures because they are responsible to facilitate this process by even including themselves in peoples training and process development.

\subsection{Facilitate Knowledge Creation Process}

Respective structures have the responsibility to facilitate knowledge creation inside organization. This requires concentration on that knowledge that is necessary to accomplish the mission in the future. Nonaka and Takeuchi ${ }^{x x i}$ argue that middle level manager play a key role in facilitating knowledge creation process in organizations. They serve as a strategic node, which joints upper level managers with them of the ground level or a bridge between idealistic visionaries of higher levels with realities of daily life displayed in human activities.

\subsection{Consulting Role for HR Managers}

HRD consultants are to consult on personnel issues in order to avoid unnecessary job displacements. Lester ${ }^{\text {xxii }}$ argues that a consultant of HRD has to be included in selection process, motivation and displacement of people and to consult the organization on knowledge they need for the future. This has certainly to be reflected in the strategic plans for 
recruitment, training and progress in career. On the other hand, it shows the necessity of including the appropriate consultants in human resource planning and administration. For instance in cases when the number is reduced thanks to reforms it is necessary for HR Consultants to be very good ones. Their main role is to determine the potential individuals for the future. This is very important during transformation process and implementing the new structure.

\subsection{Builders of Infrastructure}

Moreover, the role of HRD Consultants is to assure and build the necessary infrastructure for KM inside the organization. According to Cannell ${ }^{x x i i i}$ HR Consultants do not have any other choice beside to integrate on line learning on employees' curricula. It is necessary to understand weakest and strongest point of the new technology and be able to identify where and when they can offer a low cost solution. According to Lank ${ }^{\text {xxiv }}$ there are four main areas:

1. Definition of tacit knowledge and explicit knowledge actual and necessary for the organization

2. Development of necessary mechanism for knowledge accumulation, dissemination and basic knowledge process

3. Definition of knowledge gap and necessary mechanism for their completeness through training

4. Management of investment process, information technology and the role for more knowledge and expertise inside the organization and taking the appropriate measures for these investments to be productive

\subsection{Initiator of Knowledge Dissemination}

Finally, HRD Consultants are initiator of knowledge inside organization. It is hoped from them to initiate knowledge dissemination and profits of organization and employees. They argue that HR Directors, under the influence of appropriate consultants, have three main roles to play and these are: improvement of knowledge inside organization, management of relations with information holders outside organization like academics, companies who have their databank etc and secure that this investment will increase the figures of economic and service indicators. For instance, HRM Directorate through its consultants made possible the connection with their counterparts in order to offer higher-level different courses for the increase of criteria's on personnel side for EU integration.

Even the success of education managers, which lay on whole of the pyramidal system, is of the principal in KM; their success will depend on many factors. Davenport ${ }^{\mathrm{xxv}}$ (1998,ibid) argues that KM requires inclusion of policies from the highest levels. It requires the support of top managers and the will of others to tell what they know. More concretely, higher-level managers create the vision, managers of middle level develop concrete concepts for their employees to understand and implement. As mentioned above, it is comprehensible that if there is a lack of will from higher-level managers' point of view and determination of other levels to disseminate their knowledge and that knowledge adopted from appropriate 
structures, HRD Consultants cannot realize their duties and play their role in organizations.

\section{Conclusions}

$\mathrm{KM}$ is a development process, requirement, inclusion and use of knowledge of employees for the development and stability inside the organization. It includes four dimensions: knowledge creation as part of the individual, its dissemination and use. The goal of KM is its dissemination through personalization and codification. Personalization is the process of knowledge dissemination that supports human factors of a team. Meanwhile, codification remains in the extracts and placements of explicit knowledge in documents as CD-ROM, computers, manuals and other means of preservation. In this way, the organization has the practical possibilities to use them, through different means.

$\mathrm{KM}$ is still a new concept and research shows that still it is not expanded in private and public sector.

For the appropriate structures of HRM, KM makes possible the role of knowledge dissemination protagonist as well as creation, consultation of managers for the management of their employees. They will be builders of the necessary learning infrastructure for their employees to learn and gain the appropriate abilities. However, the effectiveness of such structures will depend on the support of higher-level managers. Such a conclusion is drawn because KM requires political support that on its own requires a clear vision in the organization.

\section{References}

Baumard, P. (1999). Tacit Knowledge in Organisation. London :Sage Publication

Buchanan and Huczynski (1977). Organisational Behaviour: An Introductory Text, 3rd edn.Gosport : Ashford Colour Press Limited

Davenport and Laurence Prusak (1998). Working Knowledge: How Organisation Manage, What they know. Boston: Harvard Business School Press.

Harrison, R. (2000). Employee Developement, $2^{\text {nd }}$ edn.Wiltshire : The Cromwell Press.

Hansen, Nohria, and Tierney (1999), «What is your strategy for Managing, Knowledge. «Harvard Business Review, March-April

Lester, T. (1998) Knowledge Management.

McAdam and Reid (2000). «A Comparison of Public and Private Sector Perception and use of Knowledge Management. Journal of Europian Industrial Training, Vol.24

Nonaka and Takeuchi (1995). The Knowledge Creating Company: How Japanese Companies Create the Dynamics of Innovation. New York: Oxford University Press.

Scarbrough and Jasky Swan (1999), Issues in People Management: Case Studies in Knowledge, Wiltshire: The Cromwell Press. 
Webb, S. (1998), Knowledge Management: Linchpin of Change, London: Aslib Staple Hall.

Walton, J. (1999), Strategic Human Resource Development. Trowbridge: Redwood Books Limited.

Willard, N. (1999), « Knowledge Management : Foundation for a Secure Structure, Journal of Managing Information, Vol.16 No.5

\footnotetext{
${ }^{\text {i }}$ Harrison, R. (2000). Employee Developement, $2^{\text {nd }}$ ed.Wiltshire : The Cromwell Press, pg.80-85

ii Willard, N. (1999), «Knowledge Management: Foundation for a Secure Structure, Journal of Managing Information, Vol.16 No.5, pg.115-120

iii Davenport, and Laurence Prusak (1998). Working Knowledge : How Organisation Manage, What they know. Boston : Harvard Business School Press., pg.280-285

iv Davenport, and Laurence Prusak (1998). Working Knowledge : How Organisation Manage, What they know. Boston : Harvard Business School Press., pg.280-285
}

v McAdam and Reid (2000). « A Comparison of Public and Private Sector Perception and use of Knowledge Management. Journal of Europian Industrial Training, Vol.24, pg 185-187.

vi Baumard, P. (1999). Tacit Knowledge in Organisation. London : Sage Publication, pg. 80-85.

vii McAdam and Reid, 2000, Ibid.

viii Baumard, P. (1999) Ibid.

ix Buchanan and Huczynski (1977). Organisational Behaviour : An Introductory Text, 3rd edn.Gosport : Ashford Colour Press Limited.

${ }^{x}$ Walton, J. (1999), Strategic Human Resource Development. Trowbridge : Redwood Books Limited. pg, 76-84

${ }^{x i}$ Hansen, Nohria, and Tierney (1999), «What is your strategy for Managing, Knowledge. « Harvard Business Review, March-April. pg, 45-50

xii McShane \& Von Glinow Ibid, p. 63.

xiii Scarbrough and Jasky Swan (1999), Issues in People Management : Case Studies in Knowledge, Wiltshire : The Cromwell Press. pg, 135-137

xiv Ruddy Ruggles “The State of the Notion” 1998, Knowledge Management in Practice, pg. 205-210.

xv Davenport, and Laurence Prusak (1998) Ibid.

${ }^{\text {xvi }}$ McAdam and Reid (2000) Ibid. 
xvii Buchanan and Huczynski (1977) Ibid.

xviii Webb, S. (1998), Knowledge Management : Linchpin of Change, London : Aslib Staple Hall. pg. 70-85

xix Lester, T. (1998) Knowledge Management. pg. 157-160.

${ }^{x x}$ Walton, J. (1999) Ibid.pg. 76-84

xxi Nonaka and Takeuchi (1995). The Knowledge Creating Company: How Japanese Companies Create the Dynamics of Innovation. New York : Oxford University Press, p. 355-360.

xxii P Lester, T. (1998) Knowledge Management. pg. 157-160.

xxii Cannell 1999: Incentive Pay: Impact and Evolution, Institute of Personnel Management, London, pg.110-115.

xxiv Lank 1997: Leveraging invisible assets: The Human Factor, pg. 76-84.

${ }^{x x v}$ Davenport, and Laurence Prusak (1998) Ibid.

\section{Copyright Disclaimer}

Copyright for this article is retained by the author(s), with first publication rights granted to the journal.

This is an open-access article distributed under the terms and conditions of the Creative Commons Attribution license (http://creativecommons.org/licenses/by/3.0/). 